\title{
Hospitable psychotherapy
}

\section{Keith Tudor}

Keith Tudor is a professor of psychotherapy at Auckland University of Technology, and a certified teaching and supervising transactional analyst. He is the author of over 500 publications, enjoys good food and wine, and both hosting and being a guest.

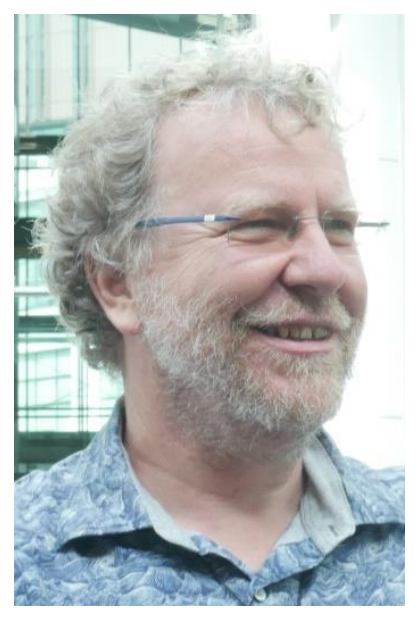

One of the things I notice when my wife and I go out for a meal in a restaurant is how the staff make contact, welcome us and see us to our table. For me, the quality of the contact (by eye contact, a smile, and an open manner), the welcome ('Kia ora'), and accompaniment to the table (which conveys a sense of being expected) are all crucial elements to setting the scene of what is to come. Similarly, in psychotherapy, practitioners meet, greet and seat their clients, and, as do restauranteurs, have different perspectives on how to do that.

During the last decade, some psychotherapists have been thinking about their practice in terms of what Donna Orange, clinician and a professor at New York University, refers to as 'clinical hospitality' [1] . In promoting this concept as a way of thinking about psychotherapeutic practice, she draws on the work of three French philosophers: Emanuel Lévinas (1906-1995), Jacques Derrida (1930-2004) and Paul Ricœur (1915-2005), all of whom devoted themselves to the discourse of hospitality. From Lévinas [2], who drew on the story of Abraham's hospitality towards three Bedouin (Genesis, chapter 18), we derive the ethical view that the 'other' as a guest has a claim on my protection as a host. This view is reflected in the duty of care towards their clients practiced by psychotherapists and those in the helping professions. Much of Derrida's work examines the ambiguities of hospitality: that it is both unconditional in that, as hosts, we submit ourselves to the other; yet, at the same time, there are 'laws' of hospitality that subject both hosting and being a guest to certain social and cultural conventions [3]. Finally, from Ricœur, a philosopher who distinguished between a hermeneutics (or way in which something is interpreted or understood) of faith or trust and a hermeneutics of doubt or suspicion, we get the concept of 'linguistic hospitality' [4]: the recognition of genuine otherness, which cannot be translated so much as interpreted. In other words, at best, there is an understanding of our guest or client, with and in all our differences. In this sense, we may think of hospitality as orientated towards being contractual, open, accepting, non-judgmental, and empathic and, insofar as it enhances a person's mana, it is therapeutic. This is akin to the concept of manaakitanga "where[by] hospitality extends beyond commercial transactions and focusses on reciprocity and care" [5], the implication of which is manaenhancing psychotherapy [6]. It is in this context that Orange, who is a psychoanalyst and a philosopher, describes her work in terms that she 'cares' for her patients $[7,8]$. 
From this perspective, psychotherapy is all about being hospitable: there is - or should be - an openness, welcome, care, and attention that makes our client/guest feel good and that sets the scene for the ensuing therapeutic relationship through which the client resolves their problems and, ultimately, feels better. Just as psychotherapy is learning from hospitality, it may be that insights from psychotherapy may be useful to people in hospitality, not only in being able to analyse transactions and interpersonal communication, but also in understanding personal history and dynamics, especially when the host is feeling less than open, welcoming or gracious. Shabad [9] emphasises the importance for the therapist to be open, precisely so that the client (or patient) has the opportunity for what he refers to as the 'dignity' to give of themselves: "When an individual has attained a sense of belonging because of being received himself/herself by significant persons, he/she is better able to mobilize the graciousness of welcoming the gifts of others" (p. 359). In other words, one cannot be a host and offer hospitality (social, cultural, linguistic, clinical or nurturant) without first having experienced, taken in and integrated, both developmentally and psychologically, appropriate and generous hospitality.

\section{Corresponding author}

Keith Tudor can be contacted at: keith.tudor@aut.ac.nz

\section{References}

(1) Orange, D. M. The Suffering Stranger: Hermeneutics for Everyday Clinical Practice; Routledge: New York, NY, 2011.

(2) Levinas, E. Nine Talmudic Readings; Indiana University Press: Bloomington, IN, 1990.

(3) Derrida, J. Adieu to Emmanuel Levinas, Trans. P.-A. Brault, M. Naas; Stanford University Press: Stanford, CA, 1999.

(4) Ricœur, P. On Translation, Trans. E. Brennan; Routledge: Hove, England, 2006.

(5) Wikitera, K.-A. Under the Stars of Matariki. Hospitality Insights 2021, 5 (1), 1-2.

(6) Reidy, J. Ko wai au? Who am I? What are the Meanings of the Mātauranga Māori Concept of Mana and What Might this Concept Contribute to the Understanding and Practice of Psychodynamic Psychotherapy?; Master's Thesis, Auckland University of Technology, New Zealand, 2014. https://openrepository.aut.ac.nz/handle/10292/7863 (accessed Dec 22, 2021).

(7) Orange, D. Clinical Hospitality: Welcoming the Face of the Devastated Other. Ata: Journal of Psychotherapy Aotearoa New Zealand 2012, 16 (2), 165-178. https://doi.org/10.9791/ajpanz.2012.17

(8) Orange, D. M. Emotional Availability and Clinical Hospitality; Presentation at Association for Psychoanalytic Self Psychology, New York City, March 2014.

(9) Shabad, P. The Vulnerability of Giving: Ethics and the Generosity of Receiving. Psychoanalytic Inquiry 2017, 37 (6), 359-374.

https://doi.org/10.1080/07351690.2017.1334443 